한우수소의 부위별 영양성분조성 및 이화학적 육질특성

조수현 · 박범영 · 김진형 • 최연호 • 성필남 · 정완태 · 정명옥 · 김동훈 · 안종남

농촌진흥청 축산과학원

\title{
Nutritional Composition and Physico-chemical Meat Quality Properties of Korean Hanwoo Bull Beef
}

S. H. Cho, B. Y. Park, J. H. Kim, Y. H. Choi, P. N. Seong, W. T. Chung, M. O. Chung,

D. H. Kim and C. N. Ahn

National Institute of Animal Science, RDA

\begin{abstract}
This study was conducted to investigate the nutritional composition and meat quality properties of Hanwoo bull beef by different cut. 10 cuts Abjin (short plate), Bosup (top sirloin), Cheggt (striploin), Dngsim (loin), Guri (chuck tender), Hongduke (eye of round), Moksim (chuck roll), Sulgit (bottom round), Udoon (top round), Yangi(brisket)] were prepared from 10 Hanwoo bulls ( $\sim 24$ months old) slaughtered during 3 consecutive days. There was no significant difference in $\mathrm{pH}$ values of 10 cuts $(\mathrm{p}>0.05)$. Udoon had the significantly higher protein contents (22.80\%), whereas Dngsim, Guri, Moksim and Yangi had the significantly lower protein contents among 10 cuts $(\mathrm{p}<0.05)$. Dngsim was highest and Hongduke was lowest in fat contents when compared to the other cuts $(\mathrm{p}<0.05)$. Abjin had significantly higher $\mathrm{L}^{*}$ and $\mathrm{b}^{*}$ values, whereas Hongduke had significantly higher $a^{*}$ values than the other cuts $(p<0.05)$. Dngsim had lower cooking loss (\%) and Warner-Bratzler shear force (WBS) and higher water holding capacity (WHC) when compared to the other cuts $(\mathrm{p}<0.05)$. Guri had higher cooking loss $(\%)$ and WBS, whereas it has lower WHC when compared to the other cuts $(\mathrm{p}<0.05)$. Total amino acid contents were significantly higher in Udoon whereas they were significantly lower in Guri and Yangi than the other cuts $(p<0.05)$. Glutamate contents were high in all cuts and followed by aspartate and lysin. In mineral contents, Fe was highly contained in Bosup, Sulgit and Yangi, and Zn was highly contained in Dngsim and Moksim $(\mathrm{p}<0.05)$.
\end{abstract}

(Key words : Hanwoo bull beef, Meat quality, Nutritional composition)

$$
\text { I. 서 론 }
$$

현재까지 한우 사육 총 가구수는 약 184,511 호 수준이며 사육 두수는 총 2,006 천두로 암 소가 1,345 천두이고 수소가 661 천두로 보고 되었다 (MAF, 2007). 수소는 평균 도체중량이 $365.1 \mathrm{~kg}$ 으로 암소와 거세우가 각각 $254.5 \mathrm{~kg}$ 과 $347.9 \mathrm{~kg}$ 수준인 것과 비교하여 가장 클 뿐 아
니라 고기생산량도 도체중량의 약 $72.92 \%$ 정도 여서 암소와 거세우가 각각 $69.71 \%, 69.29 \%$ 인 것과 비교하여 가장 높은 것으로 나타났다. 그 러나 2007년도 한우고기의 등급출현율을 보면 1 등급이상 출현율이 암소가 $61.2 \%$, 거세우가 $70.6 \%$ 인데 반하여 수소는 $3.1 \%$ 수준이었으며 오히려 3 등급 출현율이 $75.1 \%$ 이었다(APGS, 2007).

Corresponding author : S. H. Cho, Quality control and Utilization Division National Institute of Animal Science, 564 Omokchun-dong, Kwonsun-gu, Suwon, 441-350, Korea

Tel : 031-290-1703, Fax : 031-290-1697, E-mail : shc0915@rda.go.kr 
일반적으로 수소고기는 거세우고기 보다 육 색이 더 진하고 조직감이 더 거칠어 육질이 떨 어지는 것으로 알려져 있는데 (Field, 1971; Berry et al., 1972; Jeremiah, 1978), 특히 어린 수소고기가 거세우 고기보다 더 질기고 연도의 편차가 많고 육색도 진하다고 알려져 있다

(Seideman et al., 1982). Weninger and Steinhauf (1968)과 Watson (1969)의 보고에 의하면 수소와 거세우의 미오글로빈 함량은 비슷하다고 하였 으나 사실상 수소가 공격적이고 쉅게 스트레스 를 받는 기질이 있어 거세우보다 암적색육 발 생이 더 많다고 하였다 (Field, 1971). 관능특성 에 있어서 연도는 근원섬유 단백질과 근육내 결체조직 단백질의 특성에 의해 가장 큰 영향 을 받는데 특히 결체조직 단백질 중 근육내 콜 라겐의 함량은 고기의 연도와 밀접한 관련성을 가지고 있다고 알려져 있다. 김 등(1996)의 연 구결과에 의하면 수소의 경우, 부위에 관계없 이 거세우보다 콜라겐 함량이 많은 경향을 보 였고, 거세유무에 관계없이 우둔이 등심보다 콜라겐함량이 많은 경향을 나타내었다고 하였 다. 향미특성에 관하여, Reagan 등(1971)은 12개 월령에는 거세우 고기가 수소고기보다 향미가 더 강했으나 수소고기 스테이크는 12 개월 이후 부터 좋지않은 향미를 가졌다고 보고하였다. Field 등(1966)도 마블링 수준이 비슷한 같은 연령에서는 향미와 다즙성이 수소의 연령에 유 의적인 영향을 미치지 않았으나 연령이 높을수 록 향미강도가 떨어졌다고 보고하였다. Arthaud 등(1977)은 연령이 수소의 다즙성과 향미 점수 에 영향을 미친다고 보고하였다. 그러나 일반 적으로 수소와 거세우의 고기향미는 차이가 없 는 것으로 알려져 있다.

한편, 국내 쇠고기 부위별 상품은 대분할 10 개 부위 및 소분할 29개 부위로 나누어져 있으 며(농림부고시 제 2005-50호) 부위마다 성분조 성 및 육질 차이로 요리방법 및 용도에 따라 다양하게 이용되고 있다. 등급판정 및 육질 특 성의 가장 기본이 되는 등심이나 채끝부위는 고기의 결이 가늘고 육질이 좋고 적당한 지방 이 침착되어 있어 조리시 연도와 풍미가 좋은 반면에 목심부위는 운동량이 많은 부위로 근인
대가 많은 부위이다(농림기술개발사업최종보고 서, 2001). 양지머리부위는 근육과 지방교잡이 좋으면서 고기가 얇고 단단한 반면 업진부위는 호흡시 운동하는 근육으로 다소 결이 거칠고 질기지만 지방과 적육이 혼합되어 풍미가 좋은 것으로 알려져 있다. 설깃부위는 적육이 많고 근섬유가 거칠고 단단하며 우둔은 지방이 적고 적육이 많으며 고기결이 거칠다. 한편 보섭부 위는 육색이 선명하고 결은 가늘지만 지방과 적육비율이 적절하고 또한 등심보다 연하여 스 테이크로 이용되는 부위이다. 이와 같이 각 부 위별 근육내 성분조성 및 근육특성에 따라 다 양한 육질특성을 가지고 있다는 것은 잘 알려 져 있음에도 불구하고 현재까지 쇠고기 연구는 주로 등심이나 우둔부위 위주로 특성을 조사하 는 경향이었다. 또한 대부분이 거세우에 한정 된 연구가 많았으며 한우수소고기에 대한 육질 및 영양학적 조성에 관한 연구는 그리 많지 않 은 실정이다. 따라서 본 연구의 목적은 한우수 소고기의 부위별 성분조성 및 육질특성을 조사 하고자 수소 10 두에서 10 부위를 선정하여 성분 조성 및 육질특성을 분석하였다.

\section{ㅍ. 재료 및 방법}

\section{1. 공시재료}

본 연구에 사용된 시료는 축산과학원 한우시 험장에서 사육된 수소( 24개월) 10 두를 공시축 으로 이용하였으며 각 소들은 3 일에 걸쳐 정상 적인 방법으로 도축하였다. 도축 후 도체는 $1^{\circ} \mathrm{C}$ 냉각실에 저장하였다. 다음 날 마지막 흉 추와 제 1 요추 사이를 절개한 등심근육을 등 급판정사에 의하여 측정하여 평가된 도체평가 에서 모두 3등급 판정을 받았다. 수소도체들은 농림부고시(제 2005-50호)에 따라 제작된 '쇠 고기 부분육 분할 정형 지침서’(1997)에 준하여 발골하여 총 10 부위 [등심(loin), 채끝(striploin), 목심(chuck roll), 꾸리(chuck tender), 업진(short plate), 양지머리(brisket), 설깃(bottom round), 보 섭(top sirloin), 홍두깨(eye of round) 및 우둔(top round)] 를 분리하여 진공 포장한 다음 $2^{\circ} \mathrm{C}$ 숙 
성실에서 약 7 일간 숙성시키고 분석에 이용하 였다.

\section{2. 일반성분 분석}

단백질, 수분, 지방, 회분 분석은 $\mathrm{AOAC}$ (1995)에 준하여 분석하였다. 지방 및 수분 함 량은 CEM 자동추출장치 (Labwave 9000/FAS 9001, CEM Corp., Matthews, NC, USA)를 이용 하여 측정하였다. 단백질은 Kjeltec System(Kjeltec Auto 2400/2460, Foss Tecator AB, Höganas, Sweden)을 이용하여 분석하였으며, 회분은 회 분분석기 (MAS 7000, CEM Corp., Matthews, $\mathrm{NC}, \mathrm{USA})$ 를 이용하여 측정하였다.

3. $\mathrm{pH}$

$\mathrm{pH}$ 는 도축 후 24시간 후 좌도체 등심 제 10 늑골부위에서 $\mathrm{pH}$ meter(NWKninar $\mathrm{pH}$ K-21, Germany)를 이용하여 측정하였다.

\section{4. 가열감량, 보수력 및 전단력}

보수력(Water holding capacity, WHC)은 원심 분리법(Kristensen과 Purslow, 2001)으로 측정하 였으며, 가열감량(Cooking loss)은 등심근육을 $2.5 \mathrm{~cm}$ 두께의 스테이크 모양으로 절단하고 80 ${ }^{\circ} \mathrm{C}$ 항온수조에서 시료의 심부온도가 $70^{\circ} \mathrm{C}$ 에 도 달할 때까지 가열한 후 가열전과 가열후의 중 량차를 백분율로 계산하였으며 가열한 시료는 Wheeler 등(2000) 방법을 이용하여 전단력가 (WBS, Warner-Bratlzer shear force) 측정시료로 사용하였다.

\section{5. 육 색}

육색은 Chromameter(CR301, Minolta Co., Germany) 로 명도 $\left(\mathrm{L}^{*}\right)$, 적색도 $\left(\mathrm{a}^{*}\right)$, 황색도 $\left(\mathrm{b}^{*}\right)$ 를 $\mathrm{CIE}$ (Commision Internationale de Leclairage) 값으로 측정하였으며 이때 사용한 표준판은 $\mathrm{Y}=92.40$, $\mathrm{x}=0.3136, \mathrm{y}=0.3196$ 의 백색타일을 이용하였다.

\section{6. 아미노산 분석}

아미노산 분석을 위하여 고기시료 $5 \mathrm{~g}$ 와 $6 \mathrm{~N}$ $\mathrm{HCl} 40 \mathrm{ml}$ 를 둥근플라스크에 넣고 혼합한 다음 $110^{\circ} \mathrm{C}$ 에서 24 시간동안 질소가스를 주입하여 가 수분해하였다. 염산을 $50^{\circ} \mathrm{C}$ 에서 증발농축시킨 다음 농축시료는 $0.2 \mathrm{~N}$ sodium citrate buffer $(\mathrm{pH}$ 2.2) $50 \mathrm{~mL}$ 를 넣어 희석시킨 다음 여과지 $(0.45$ $\mu \mathrm{m})$ 로 여과하였다. 여과한 시료(30 $\mu \ell)$ 는 아미노 산 분석기(Alpha, LKB-4150, Hitachi, Japan) (Hitachi, model 835)를 이용하여 분석하였다.

\section{7. 무기물 분석}

무기물 함량은 $\mathrm{AOAC(1995)방법에} \mathrm{준하여} \mathrm{측}$ 정하였다.

\section{8. 통계분석}

분석결과는 SAS(1996) program을 이용하여 Student-Newman-Keul's 다중검정법으로 각 요인 간의 유의성 $(\mathrm{p}<0.05)$ 을 비교하였다.

\section{III. 결과 및 고찰}

\section{1. $\mathrm{pH}$}

10부위의 $\mathrm{pH}$ 는 5.62 5.75 범위였으며 부위 간에 유의적인 차이는 없었다( $>>0.05)(T a b l e ~ 1)$. 최종 $\mathrm{pH}$ 는 영양상태, 수송거리, 계절, 다른 우 군의 혼합 등, 도살 당시의 글리코겐의 농도에 영향을 받는데, 스트레스로 인해 글리코겐 소 모가 많은 우육은 $\mathrm{pH}$ 가 높아 DFD(dark, firm, dry)육 발생 확률이 높은 것으로 알려져 있다 (Sanz 등, 1996) 본 연구에 사용된 수소의 부위 별 $\mathrm{pH}$ 결과는 모두 정상범위에 속하는 것으로 나타났다. 김 등(1996)은 쇠고기의 $\mathrm{pH}$ 값이 품 종, 성 및 부위별에 따른 유의한 차이를 나타 내지 않았다고 보고하였다. 한편, Watanabe 등 (1996)은 $\mathrm{pH}$ 가 5.5에서 6.0으로 상승하면 연도 는 감소하며, $\mathrm{pH} 6.0$ 이상에서는 calpain 효소의 활성이 증가하여 연도가 증진된다고 보고하였 
Table 1. $\mathrm{pH}$ and chemical composition of Hanwoo bull beef by different cut

\begin{tabular}{cccccc}
\hline Cut & $\mathrm{pH}$ & $\begin{array}{c}\text { Protein } \\
(\%)\end{array}$ & $\begin{array}{c}\text { Moisture } \\
(\%)\end{array}$ & $\begin{array}{c}\text { Fat } \\
(\%)\end{array}$ & $\begin{array}{c}\text { Ash } \\
(\%)\end{array}$ \\
\hline \hline \multirow{2}{*}{ Apjin } & $5.69^{*}$ & $21.66^{\mathrm{bc}}$ & $74.78^{\mathrm{b}}$ & $2.09^{\mathrm{ab}}$ & $0.89^{\mathrm{c}}$ \\
& $(0.05)$ & $(0.33)$ & $(0.72)$ & $(0.82)$ & $(0.02)^{\mathrm{d}}$ \\
\hline \multirow{2}{*}{ Bosup } & 5.62 & $22.24^{\mathrm{abc}}$ & $74.63^{\mathrm{b}}$ & $1.52^{\mathrm{bc}}$ & $0.94^{\mathrm{abc}}$ \\
& $(0.06)$ & $(0.20)$ & $(0.85)$ & $(0.79)$ & $0.03)$ \\
\hline \multirow{2}{*}{ Cheggt } & 5.72 & $22.35^{\mathrm{ab}}$ & $74.13^{\mathrm{b}}$ & $1.75^{\mathrm{bc}}$ & $0.93^{\mathrm{abc}}$ \\
& $(0.12)$ & $(0.22)$ & $(0.57)$ & $(0.43)$ & $(0.01)$ \\
\hline \multirow{2}{*}{ Dngsim } & 5.71 & $21.32^{\mathrm{c}}$ & $74.03^{\mathrm{b}}$ & $2.85^{\mathrm{a}}$ & $0.85^{\mathrm{cd}}$ \\
& $(0.07)$ & $(0.35)$ & $(0.64)$ & $(0.05)$ & $(0.02)$ \\
\hline \multirow{2}{*}{ Guri } & 5.70 & $21.47^{\mathrm{c}}$ & $75.79^{\mathrm{a}}$ & $1.19^{\mathrm{b}}$ & $0.80^{\mathrm{d}}$ \\
& $(0.04)$ & $(0.26)$ & $(0.54)$ & $(0.73)$ & $(0.05)$ \\
\hline \multirow{2}{*}{ Hongduke } & 5.73 & $22.49^{\mathrm{ab}}$ & $75.65^{\mathrm{a}}$ & $0.65^{\mathrm{c}}$ & $1.01^{\mathrm{a}}$ \\
& $(0.08)$ & $(0.23)$ & $(0.46)$ & $(0.39)$ & $(0.03)$ \\
\hline \multirow{2}{*}{ Moksim } & 5.75 & $21.38^{\mathrm{c}}$ & $75.86^{\mathrm{a}}$ & $1.23^{\mathrm{b}}$ & $0.87^{\mathrm{cd}}$ \\
& $(0.05)$ & $(0.30)$ & $(0.46)$ & $(0.27)$ & $(0.02)$ \\
\hline \multirow{2}{*}{ Sulgit } & 5.65 & $22.19^{\mathrm{abc}}$ & $75.08^{\mathrm{ab}}$ & $1.04^{\mathrm{b}}$ & $0.94^{\mathrm{abc}}$ \\
& $(0.06)$ & $(0.19)$ & $(0.35)$ & $(0.25)$ & $(0.01)$ \\
\hline \multirow{2}{*}{ Udoon } & 5.63 & $22.80^{\mathrm{a}}$ & $74.50^{\mathrm{b}}$ & $0.98^{\mathrm{b}}$ & $0.99^{\mathrm{ab}}$ \\
& $(0.08)$ & $(0.23)$ & $(0.61)$ & $(0.38)$ & $(0.03)$ \\
\hline \multirow{2}{*}{ Yanggi } & 5.67 & $21.35^{\mathrm{c}}$ & $75.82^{\mathrm{a}}$ & $1.06^{\mathrm{b}}$ & $0.91^{\mathrm{bc}}$ \\
& $(0.05)$ & $(0.28)$ & $(0.43)$ & $(0.33)$ & $(0.01)$ \\
\hline
\end{tabular}

a-d Means within the same column having the different superscript were significantly $\operatorname{different}(\mathrm{p}<0.05)$

* Mean(standard error)

다. Kim 등(2002)도 $\mathrm{pH}$ 는 등급간이나 성별간 유의차가 없었으며, 거의 모든 개체에서 $\mathrm{pH}$ $5.4 \sim 5.5$ 범위의 $\mathrm{pH}$ 를 보였다고 하였다.

\section{2. 일반성분}

일반조성에서 단백질 함량은 우둔부위가 $22.80 \%$ 로 가장 높았으며 등심, 꾸리, 목심 및 양지부 위가 유의적으로 낮은 경향을 나타냈다 $(\mathrm{p}<$ 0.05). 지방 함량은 등심 부위가 높았고 홍두깨 부위가 낮은 경향을 나타냈다 $(\mathrm{p}<0.05)$. 수분 함 량은 74.03 75.86\% 범위였는데 꾸리, 홍두깨, 목심 및 양지부위가 가장 높은 반면에 채끝, 업진, 보섭 및 우둔부위에서는 가장 낮게 나타 났다 $(\mathrm{p}<0.05)$. 회분 함량은 홍두깨 부위가 가장 높았고 꾸리부위가 가장 낮은 경향을 나타냈다 $(\mathrm{p}<0.05) . \mathrm{Kim}$ 등(2002)은 육질등급별 한우 등심 부위의 일반성분을 분석한 결과 수분 함량이 근내지방 함량이 가장 낮은 3 등급 비거세우에
서 가장 높은 수치를 보였다고 하였다. 본 연 구에서는 우둔부위가 등심과 비교하여 단백질 함량과 회분 함량이 높았고, 등심부위가 우둔 부위보다 지방 함량이 유의적으로 높았으나 $(\mathrm{p}<0.05)$, 수분 함량은 두 부위간에 유의적인 차이는 없는 것으로 나타났다( $p>0.05)$. 김 등 (1996)은 한우 비거세우가 동일한 부위의 한우 거세우보다 수분 함량이 낮고 지방 함량이 높 은 수준이었다고 하였으며, 부위별로는 우둔의 수분 함량은 전반적으로 등심에 비하여 높았다 고 보고하였다. 조지방 함량에서는 등심의 경 우 한우거세우가 비거세우보다 높게 나타났으 며, 우둔의 부위가 등심에 비하여 함량은 낮았 는데 이러한 경향은 품종과 성별에 관계없이 등심에서와 같은 경향을 나타내었다. 이는 품 종 및 성간에 수분 함량과 지방 함량간에 서로 역의 관계가 있다는 여러 연구자들과 일치하는 경향이었다(吉田 등, 1968; Jacobs 등, 1977; Landon 등, 1978; 이 등, 1981; 백 등, 1992). 
Table 3. Amino acid compositions(\%) of Hanwoo bull beef by different cut

\begin{tabular}{|c|c|c|c|c|c|c|c|c|c|c|}
\hline AA & G & M & $\mathrm{C}$ & $\mathrm{U}$ & $\mathrm{H}$ & Y & A & S & B & D \\
\hline Cys*** & $\begin{array}{l}0.24^{\mathrm{b}} * * \\
(0.02)\end{array}$ & $\begin{array}{r}0.25^{\mathrm{a}} \\
(0.01)\end{array}$ & $\begin{array}{c}0.25^{\mathrm{a}} \\
(0.01) \\
\end{array}$ & $\begin{array}{c}0.26^{\mathrm{a}} \\
(0.01)\end{array}$ & $\begin{array}{c}0.25^{\mathrm{a}} \\
(0.01)\end{array}$ & $\begin{array}{c}0.24^{\mathrm{ab}} \\
(0.01)\end{array}$ & $\begin{array}{c}0.24^{\mathrm{ab}} \\
(0.01)\end{array}$ & $\begin{array}{r}0.25^{\mathrm{a}} \\
(0.02)\end{array}$ & $\begin{array}{c}0.26^{\mathrm{a}} \\
(0.02)\end{array}$ & $\begin{array}{c}0.25^{\mathrm{ab}} \\
(0.02)\end{array}$ \\
\hline Meth & $\begin{array}{c}0.48^{\mathrm{d}} \\
(0.02)\end{array}$ & $\begin{array}{c}0.50^{c} \\
(40.02)\end{array}$ & $\begin{array}{c}0.54^{\mathrm{ab}} \\
(0.03)\end{array}$ & $\begin{array}{c}0.54^{\mathrm{a}} \\
(0.03)\end{array}$ & $\begin{array}{c}0.54^{\mathrm{ab}} \\
(0.02)\end{array}$ & $\begin{array}{c}0.51^{\text {bc }} \\
(0.03)\end{array}$ & $\begin{array}{l}0.52^{\mathrm{abc}} \\
(0.04)\end{array}$ & $\begin{array}{c}0.53^{\mathrm{abc}} \\
(0.03)\end{array}$ & $\begin{array}{l}0.53^{\mathrm{abc}} \\
(0.03)\end{array}$ & $\begin{array}{c}0.51^{c} \\
(0.04) \\
\end{array}$ \\
\hline Asp & $\begin{array}{c}1.99^{\mathrm{C}} \\
(0.10)\end{array}$ & $\begin{array}{c}2.03^{\text {bc }} \\
(0.09)\end{array}$ & $\begin{array}{l}2.12^{\mathrm{ab}} \\
(0.07)\end{array}$ & $\begin{array}{c}2.17^{\mathrm{a}} \\
(0.09)\end{array}$ & $\begin{array}{l}2.10^{\mathrm{ab}} \\
(0.07)\end{array}$ & $\begin{array}{l}2.01^{\mathrm{bc}} \\
(0.07)\end{array}$ & $\begin{array}{r}2.03^{\mathrm{c}} \\
(0.11) \\
\end{array}$ & $\begin{array}{c}2.09^{\mathrm{ab}} \\
(0.06)\end{array}$ & $\begin{array}{c}2.11^{\mathrm{ab}} \\
(0.10)\end{array}$ & $\begin{array}{c}2.02^{\mathrm{bc}} \\
(0.15)\end{array}$ \\
\hline Thr & $\begin{array}{c}0.98 \\
(0.05)\end{array}$ & $\begin{array}{c}1.01 \\
(0.05) \\
\end{array}$ & $\begin{array}{c}1.06 \\
(0.03) \\
\end{array}$ & $\begin{array}{c}1.08 \\
(0.04) \\
\end{array}$ & $\begin{array}{c}0.94 \\
(0.34) \\
\end{array}$ & $\begin{array}{c}1.00 \\
(0.04) \\
\end{array}$ & $\begin{array}{c}1.01 \\
(0.05) \\
\end{array}$ & $\begin{array}{c}1.04 \\
(0.03) \\
\end{array}$ & $\begin{array}{c}1.06 \\
(0.05) \\
\end{array}$ & $\begin{array}{c}1.01 \\
(0.08) \\
\end{array}$ \\
\hline Ser & $\begin{array}{c}0.89^{b} \\
(0.04)\end{array}$ & $\begin{array}{c}0.89^{\mathrm{b}} \\
(0.04)\end{array}$ & $\begin{array}{l}0.93^{\mathrm{ab}} \\
(0.03)\end{array}$ & $\begin{array}{c}0.94^{\mathrm{a}} \\
(0.04)\end{array}$ & $\begin{array}{c}0.92^{\mathrm{ab}} \\
(0.04)\end{array}$ & $\begin{array}{r}0.89^{\mathrm{b}} \\
(0.02)\end{array}$ & $\begin{array}{c}0.89^{b} \\
(0.05)\end{array}$ & $\begin{array}{c}0.91^{\mathrm{ab}} \\
(0.03)\end{array}$ & $\begin{array}{c}0.92^{\mathrm{ab}} \\
(0.05)\end{array}$ & $\begin{array}{c}0.89^{\mathrm{b}} \\
(0.07)\end{array}$ \\
\hline Glu & $\begin{array}{c}3.64^{\mathrm{ab}} \\
(0.17) \\
\end{array}$ & $\begin{array}{c}3.73^{\mathrm{ab}} \\
(0.21) \\
\end{array}$ & $\begin{array}{c}3.72^{\mathrm{ab}} \\
(0.14) \\
\end{array}$ & $\begin{array}{r}3.82^{\mathrm{a}} \\
(0.14) \\
\end{array}$ & $\begin{array}{c}3.74^{\mathrm{ab}} \\
(0.15) \\
\end{array}$ & $\begin{array}{r}3.60^{\mathrm{b}} \\
(0.14) \\
\end{array}$ & $\begin{array}{c}3.64 \\
(0.20) \\
\end{array}$ & $\begin{array}{c}3.17^{\mathrm{ab}} \\
(0.11) \\
\end{array}$ & $\begin{array}{c}3.74^{\mathrm{ab}} \\
(0.09) \\
\end{array}$ & $\begin{array}{c}3.66^{\mathrm{ab}} \\
(0.21) \\
\end{array}$ \\
\hline Gly & $\begin{array}{c}1.02^{\mathrm{a}} \\
(0.10)\end{array}$ & $\begin{array}{c}0.96^{\mathrm{ab}} \\
(0.05)\end{array}$ & $\begin{array}{c}0.96^{\mathrm{ab}} \\
(0.03)\end{array}$ & $\begin{array}{c}0.98^{\mathrm{ab}} \\
(0.02)\end{array}$ & $\begin{array}{c}1.01^{\mathrm{ab}} \\
(0.04)\end{array}$ & $\begin{array}{c}1.01^{\mathrm{ab}} \\
(0.10)\end{array}$ & $\begin{array}{c}1.03 \\
(0.13)\end{array}$ & $\begin{array}{c}0.98^{\mathrm{ab}} \\
(0.05)\end{array}$ & $\begin{array}{c}0.95^{\text {ab }} \\
(0.05)\end{array}$ & $\begin{array}{c}0.93^{\mathbf{b}} \\
(0.05)\end{array}$ \\
\hline Ala & $\begin{array}{c}1.26 \\
(0.05)\end{array}$ & $\begin{array}{c}1.27 \\
(0.05)\end{array}$ & $\begin{array}{c}1.31 \\
(0.04)\end{array}$ & $\begin{array}{c}2.24 \\
(2.86)\end{array}$ & $\begin{array}{c}1.33 \\
(0.04)\end{array}$ & $\begin{array}{c}1.27 \\
(0.02)\end{array}$ & $\begin{array}{c}1.28 \\
(0.08)\end{array}$ & $\begin{array}{c}1.30 \\
(0.03)\end{array}$ & $\begin{array}{c}1.31 \\
(0.06)\end{array}$ & $\begin{array}{c}1.26 \\
(0.08)\end{array}$ \\
\hline Val & $\begin{array}{c}0.90^{c} \\
(0.05) \\
\end{array}$ & $\begin{array}{r}0.92^{\mathrm{c}} \\
(0.04)\end{array}$ & $\begin{array}{c}0.97^{\mathrm{ab}} \\
(0.03)\end{array}$ & $\begin{array}{c}1.00^{\mathrm{a}} \\
(0.04)\end{array}$ & $\begin{array}{c}0.97^{\mathrm{ab}} \\
(0.03)\end{array}$ & $\begin{array}{c}0.93^{\mathrm{bc}} \\
(0.04)\end{array}$ & $\begin{array}{c}0.93^{\mathrm{bc}} \\
(0.05)\end{array}$ & $\begin{array}{c}0.96^{\mathrm{ab}} \\
(0.02)\end{array}$ & $\begin{array}{c}0.97^{\mathrm{ab}} \\
(0.05)\end{array}$ & $\begin{array}{r}0.92^{\mathrm{C}} \\
(0.06) \\
\end{array}$ \\
\hline
\end{tabular}

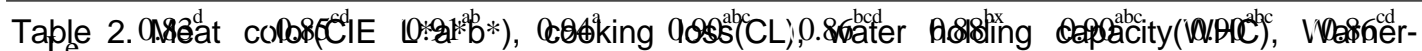
(969).

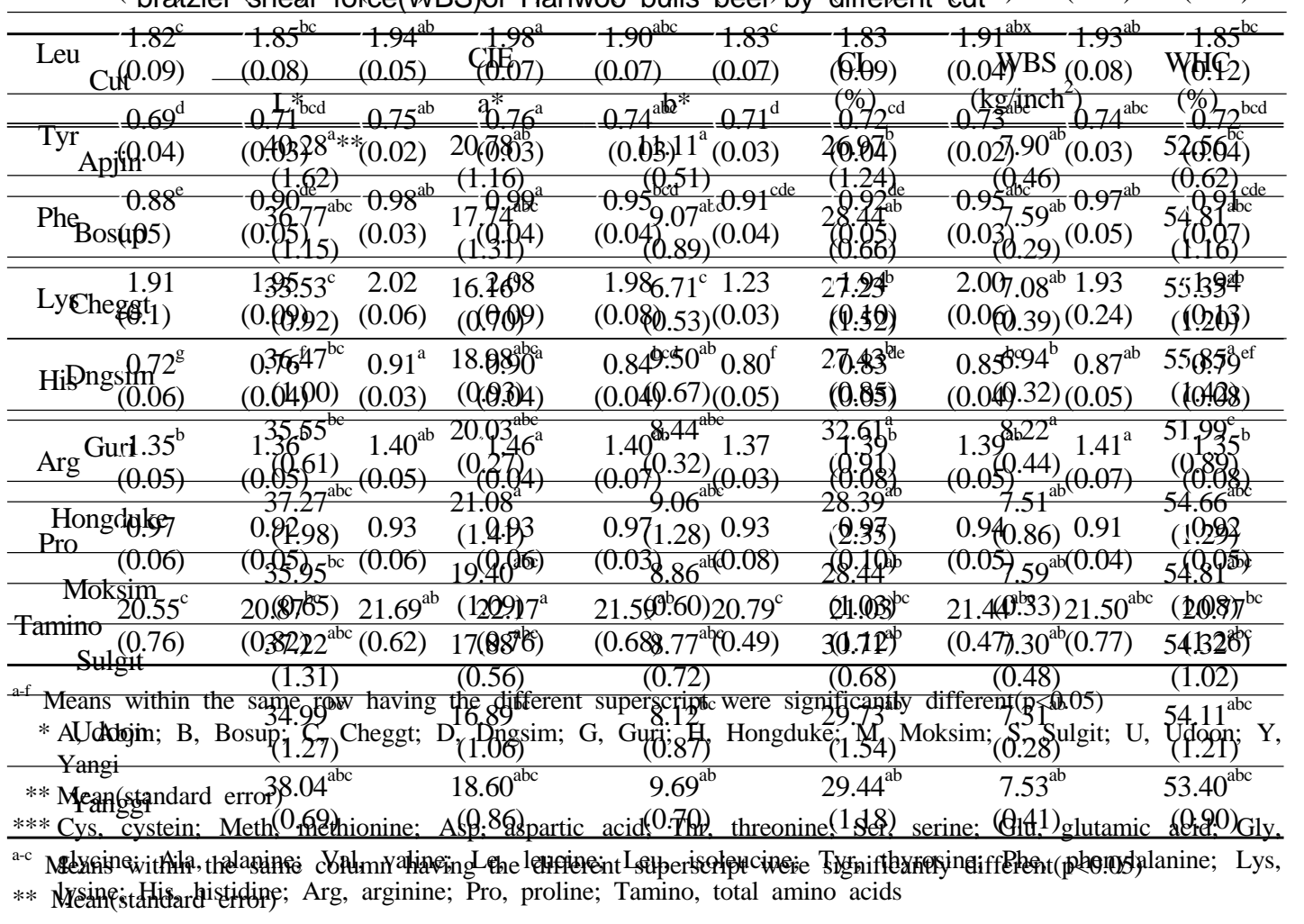




\section{3. 육색}

Table 2에 나타난 바와 같이 업진이 명도(L* 값)과 황색도(b*값)가 가장 높았고 채끝부위는 다른 부위와 비교하여 $\mathrm{L}$ *값, $\mathrm{a*}$ *값 및 $\mathrm{b} *$ 값이 모두 유의적으로 낮은 것으로 나타났다 $(\mathrm{p}<$ 0.05). 한편 홍두깨 부위가 적색도(a값)가 가장 높은 것으로 나타났다 $(\mathrm{p}<0.05)$. 우육의 육색과 지방색은 근내지방도와 함께 우육의 육질등급 을 결정하는 주요 인자일 뿐만 아니라, 소비자 의 구매 관점에서도 대단히 중요하다(Ansorena 등, 1977; Mercier 등, 1998). 우리나라의 경우 육질등급 판정시에 육색 및 지방색은 각각 No.1 No.7까지 분류하여 육색은 약한 선홍색 에서 짙은 암적색까지, 지방색은 백색에서 황 색까지 분류하고 있다(강 등, 1999). 육색은 주 로 미오글로빈(myoglobin)의 함량에 의존하며 (Lizaso 등, 1996; Sakata와 Nagata, 1992; Ibanez 등, 1995; Santamaria 등, 1992), 지방색 은 비타민 $\mathrm{A}$ 의 전구체인 $\beta$-carotenoid 함량에 의존하는 바가 크다(Yang 등, 1999; Smith 등,
1997). 김 등(1996)은 한우와 홀스타인의 성별 및 부위별로 육색을 비교한 결과 성별간에는 차이가 없었으나, 부위별로는 우둔이 등심에 비하여 높은 수준의 햄색소 함량을 가졌다고 보고하였다. 한편, 육색소인 미오글로빈 함량이 근내지방등급이 높아짐에 따라 그 함량이 줄어 들고, 성별에 따라 비거세우, 거세우, 미경산우 순으로 유의차 $(\mathrm{p}<0.001)$ 가 있었다고 보고된 바 있었다(Kim 등, 2002).

\section{4. 가열감량, 보수력 및 전단력}

가열감량은 꾸리부위가 가장 높게 나타난 반 면 채끝, 등심 및 업진 부위가 감량이 가장 낮 게 나타났다 $(\mathrm{p}<0.05)($ Table 2). 고기의 가열은 가 열방법, 성분조성 및 익힘정도에 따라 그 구조 의 변화를 야기하며 가열방법에 관계없이 고기 가 가열될 때 근섬유의 수축과 근절의 단축은 보수력의 감소와 가열감량을 나타내게 된다 (Bower 등, 1987). 부위별로 가열감량은 등심이 우둔에 비하여 낮아 김 등(1999)과 백 등(1992)

Table 4. Mineral contents $(\mathrm{mg} / \mathrm{kg})$ for Hanwoo bull beef by different cut

\begin{tabular}{cccc}
\hline Cut & $\mathrm{Ca}$ & $\mathrm{Fe}$ & $\mathrm{Zn}$ \\
\hline \hline \multirow{2}{*}{ Cheggt } & 156.42 & $30.12^{\mathrm{ab}}$ & $54.56^{\mathrm{ab}}$ \\
& $(23.60)$ & $(2.53)$ & $(3.78)$ \\
\hline \multirow{2}{*}{ Abjin } & 150.44 & $20.68^{\mathrm{b}}$ & $41.52^{\mathrm{b}}$ \\
& $(18.15)$ & $(2.32)$ & $(3.57)$ \\
\hline \multirow{2}{*}{ Guri } & 144.66 & $28.41^{\mathrm{ab}}$ & $60.27^{\mathrm{a}}$ \\
& $(18.78)$ & $(2.62)$ & $(3.53)$ \\
\hline \multirow{2}{*}{ Bosup } & 123.71 & $32.74^{\mathrm{a}}$ & $49.98^{\mathrm{ab}}$ \\
& $(16.02)$ & $(2.98)$ & $(2.49)$ \\
\hline \multirow{2}{*}{ Moksim } & 142.50 & $29.73^{\mathrm{ab}}$ & $59.53^{\mathrm{a}}$ \\
& $(21.36)$ & $(2.56)$ & $(2.81)$ \\
\hline \multirow{2}{*}{ Yanggi } & 140.63 & $33.33^{\mathrm{a}}$ & $52.07^{\mathrm{ab}}$ \\
& $(21.26)$ & $(2.17)$ & $(2.51)$ \\
\hline \multirow{2}{*}{ Dngsim } & 135.00 & $29.15^{\mathrm{ab}}$ & $\left(2.67^{\mathrm{a}}\right.$ \\
& $(16.04)$ & $(2.80)$ & $49.82^{\mathrm{ab}}$ \\
\hline \multirow{2}{*}{ Hongduke } & 132.33 & $23.93^{\mathrm{ab}}$ & $(3.34)$ \\
\hline \multirow{2}{*}{ Sulgit } & $(13.01)$ & $(1.59)$ & $53.92^{\mathrm{ab}}$ \\
& 144.09 & $33.07^{\mathrm{a}}$ & $(6.65)$ \\
\hline \multirow{2}{*}{ Udoon } & $(16.39)$ & $(2.83)$ & $48.89^{\mathrm{ab}}$ \\
& 120.97 & $29.39^{\mathrm{ab}}$ & $(4.10)$ \\
\hline
\end{tabular}

${ }^{a-b}$ Means within the same column having the different superscript were significantly different $(\mathrm{p}<0.05)$

* Mean(standard error) 
의 연구 결과와 일치하는 경향이었고, 근내지 방도가 높을수록 가열감량이 적다고 한 Breidenstein 등(1968), 三律本 등 (1987) 및 김과 오 (1990)의 보고와도 일치하는 경향이었다. 전단 력은 꾸리부위가 가장 높게 나타났고 등심부위 가 가장 낮게 나타났다 $(\mathrm{p}<0.05)($ Table 2$)$. 보수력 은 꾸리부위가 가장 낮게 나타난 반면에 등심 이 가장 높게 나타났다 $(\mathrm{p}<0.05) . \mathrm{Kim}$ 등(2002)은 근내지방도가 보수력과 정 $(+)$ 의 상관관계를 가 지고 수분 함량과는 부 $(-)$ 의 상관관계를 나타 낸다고 하였고, Berry(1993)는 근내지방도가 높 을수록 전단력이 낮아진다고 하였는데 이러한 경향은 본 연구결과와도 일치하였다. 본 연구 에서 등심의 경우 근육내 지방 함량과 보수력 이 다른 부위들과 비교하여 가장 높았고 반대 로 전단력 수치는 가장 낮게 나타났다 $(\mathrm{p}<0.05)$. 비슷한 경향으로 수분 함량이 높고 지방 함량 이 적었던 꾸리, 홍두깨, 목심, 양지부위 중에 서 꾸리부위가 가열감량과 전단력 수치가 다른 부위와 비교하여 가장 높았고 반면에 보수력 가장 낮은 것으로 분석되었다 $(\mathrm{p}<0.05)$. 김 등 (1996)에 의하면 보수력은 품종과 부위에 관계 없이 거세우가 비거세우에 비하여 높았으며, 부위별로는 등심이 우둔에 비하여 높은 경향이 었다고 보고함으로서 근내지방도와 관련이 있 는 것으로 생각된다. 김 등(1982)과 채 등(1983) 도 한우육의 등심 및 배최장근의 보수력이 뒷 다리 및 반건양근에 비하여 높다고 하였는데, 본 연구에서는 등심과 우둔의 보수력은 수치적 으로는 등심이 더 높았으나 두 부위간에 유의 적인 차이가 없는 것으로 나타났다( $\mathrm{p}>0.05)$.

\section{5. 아미노산}

총 아미노산 함량은 우둔부위가 높게 나타난 반면에 꾸리가 낮게 나타났다 $(\mathrm{p}<0.05)($ Table 3$)$. 모든 부위에 glutamate 함량이 가장 높은 수준 으로 존재하였고 그 다음으로 aspartate 및 lysin 순으로 높게 나타났다 $(\mathrm{p}<0.05)$. 우둔부위는 cystein, methionine, aspartate, serine, glutamate, valine, leucine, Iso-leucine, tyrosine, phenylalanine, histidine 및 arginine 함량이 다른 부위와 비교하여
가장 높은 것으로 나타났다( $<<0.05)$. 반면에 꾸 리부위는 cystein, methionine, aspartate, serine, valine, leucine, Iso-leucine, tyrosine, phenylalanine, histidine 및 arginine 함량이 다른 부위와 비교 하여 가장 낮은 것으로 나타났다 $(\mathrm{p}<0.05)$. 일반 적으로 필수 아미노산(essential amino acid)이란 생물체내에서 생합성이 되지 않는 아미노산으 로서 반드시 음식물을 통해 섭취해야 하는 아 미노산이다. 필수아미노산에는 Arginine, Histidine, soleucine, Leucine, Lysine, Methionine, Phenylalanine, Threonine, Tryptophan, Valine 등이 포 함되어 있는데, 이 중 Arginine이 유아만 해당 되고 성인은 해당되지 않는다고 한다. 본 연구 결과 한우수소고기에는 부위별로 함량에는 다 소 차이가 있으나 이러한 필수아미노산이 골고 루 함유되어 있는 것을 알 수 있었다. Godber (1994)는 성인 1 인당 1 일 $63 \mathrm{~g}$ 의 단백질이 필요 하며 특히 쇠고기는 생육내 단백질 함량이 약 $20 \%$ 로서 단백질 섭취원으로 훌륭한 식품이라 고 하였다. Cho 등(1999)의 조사에서도 $44 \%$ 소 비자들이 영양섭취를 목적으로 쇠고기르 구입 한다고 응답하였다고 하였다.

\section{6. 무기물}

쇠고기는 단백질 뿐 아니라 $\mathrm{Zn}$ 및 $\mathrm{Fe}$ 등과 같은 무기물도 풍부한 식품으로 알려져 있다 (Harrington, 1994; Bodwell, 1986). 본 연구에서 부위별 무기물 함량을 분석한 결과 10 부위간에 $\mathrm{Ca}$ 함량에는 유의적인 차이가 없었으나 $\mathrm{Fe}$ 함 량은 보섭, 양지 및 설깃 부위에서 높게 나타 났고, $\mathrm{Zn}$ 함량은 등심 및 목심부위에서 높게 분석되었다 $(\mathrm{p}<0.05)$.

\section{IV. 요 약}

본 연구는 한우수소고기의 부위별 성분조성 및 육질특성을 조사하고자 한우수소 10 두에서 10 부위(업진, 보섭, 채끝, 등심, 꾸리, 홍두깨, 목심, 설깃, 양지, 우둔)를 선정하여 성분조성 및 육질특성을 분석하였다. 10 부위의 $\mathrm{pH}$ 는 5.62 5.75 범위였으며 부위간에 유의적인 차이 
는 없었다(p>0.05). 일반조성에서 단백질 함량 은 우둔부위가 $22.8 \%$ 로 가장 높았으며 등심, 꾸리, 목심 및 양지부위가 유의적으로 낮은 경 향을 나타냈다 $(\mathrm{p}<0.05)$. 지방 함량은 등심 부위 가 가장 높았고 홍두깨부위가 가장 낮은 경향 을 나타냈다 $(\mathrm{p}<0.05)$. 부위별 육색에 있어서는 업진이 명도(L값)과 황색도(b값)가 가장 높았고 홍두깨 부위가 적색도(a값)가 가장 높은 것으로 나타났다 $(\mathrm{p}<0.05)$. 가열감량은 등심이 다른 부 위들과 비교하여 근육내 지방 함량과 보수력이 가장 높았고 반대로 전단력 수치는 가장 낮게 나타났다 $(\mathrm{p}<0.05)$. 꾸리부위는 가열감량과 전단 력 수치가 다른 부위와 비교하여 가장 높았고 반면에 보수력은 가장 낮은 것으로 분석되었다 $(\mathrm{p}<0.05)$. 총 아미노산 함량은 우둔부위가 가장 높게 나타난 반면에 꾸리와 양지부위가 낮게 나타났다 $(\mathrm{p}<0.05)$. 모든 부위에 glutamate 함량 이 가장 높은 수준으로 존재하였고 그 다음으 로 aspartate 및 lysin 순으로 높게 나타났다. 무 기물 분석결과 $\mathrm{Fe}$ 함량은 보섭, 양지 및 설깃 부위에서 높게 나타났고 $\mathrm{Zn}$ 함량은 등심 및 목 심부위에서 높게 분석되었다 $(\mathrm{p}<0.05)$.

\section{$\mathrm{V}$. 감사의 글}

이 논문은 2006년도 농촌진흥청 축산과학원 경상연구비에 의하여 연구되었으며 이에 감사 드립니다.

\section{VI. 인 용 문 헌}

1. Ansorena, D., Pena, M. P. D., Astiasaran, I. and Bello, J. 1997. Colour evaluation of chorize de pamplona, a spanish dry fermented sausage : comparison between the CIE L*a*b* and the hunter Lab systems with illuminants D65 and C. Meat Sci. 46:313-318.

2. Animal Products Grading Service. 2007. Grade information. http://www.apgs.co.kr/gradeinfo/statistics (assessed on August 30, 2007)

3. AOAC. 1995. Official methods of analysis, 15th ed. Association of Official Analytical Chemists,
Washington, DC.

4. Arthaud, V. H., Mandigo, R. W., Korh R. M. and Kotula, A. W. 1977. Carcass composition, quality, and palatability attributes of bulls and steers fed different energy levels and killed at four ages. J. Anim. Sci. 44:53-64.

5. Berry, B. W., Smith, G. C. and Carpenter, Z. L. 1972. Influence of certain physiological maturity indicators on beef tenderness. Beef Cattle Res. in texas PR-3131. p 27.

6. Berry, B. W. 1993. Tenderness of beef loin steaks as influences by marbling level, removal of subcutaneous fat and cooking method. J. Anim. Sci. 71:2412-2419.

7. Bodwell, C. E. 1986. Nutritional composition and value of meat products. Muscle as Food, 321-328.

8. Bowers, J. A., Craig, J. A., Kropf, D. H. and Tucker, T. J. 1987. Flavor, color and other characteristics of beef longissimus muscle heated to seven internal temperatures between $55^{\circ} \mathrm{C}$ and $85^{\circ} \mathrm{C}$. J. Food Sci., 52: 533-536.

9. Breidenstein, B. B., Cooper, C. C. Evans, R. G. and Bray, R. W. 1968. Influence of marbling and maturity on palatability of beef muscle. 1 . Chemical and organoleptic consideration. J. Anim. Sci. 27:1532-1536.

10. Cho, S. H., Lee, J. M., Kim, J. H., Park, B. Y., Yoo, Y. M. and Kim, Y. K. 1999. Survey of consumer perception and demand on beef market. Korean J. Food Sci. Ani. Resour. 19(4):352-360.

11. Field, R. A., Nelms, G. E. and Schoonover, C. D. 1966. Effects of age, marbling and sex on palatability of beef. J. Anim. Sci. 25:360.

12. Field, R. A. 1971. Effect of castration on meat quality and quantity. J. Anim. Sci. 32:849-858.

13. Godber, J. S. 1994. Nutritional value of muscle foods. Muscle Food, 430.

14. Harrington, G. 1994. Consumer demands: major problem facing industry in a consumer-driven society. Meat Sci. 36:5-8.

15. Ibanez, C., Quintanilla, L., Irigoyen, A., GarciaJalon, I., Cid, C., Astiasaran, I. and Bello, J. 
1995. Partial replacement of sodium choloride with potassium chloride in dry fermented sausage : Influence on carbohydrate fermentation and the nitrosation process. Meat Sci. 40:45-53.

16. Kim, M. S., Yang, J. B. and Moon, Y. H. 1999. Effects of chilling process after thawing on the free amino acid composition of beef loin. Kor. J. Food Sci. Ani. Resour. 19(3):234-239.

17. Kim, J. H., Park, B. Y., Yoo, Y. M., Cho, S. H., Kim, Y. K., Lee, J. M., Yun, H. J. and Kim, K. N. 2002. Characteristics of carcass meat yields of fattening pigs by production step. Kor. J. Anim. Sci. \& Technol. 44, 793-800.

18. Kristensen, L. and Purslow, P. P. 2001. The effect of ageing on the water-holding capacity of pork: role of cytoskeletal proteins. Meat Sci. 58, 241-247.

19. Jacobs, J. A., Miller, J. C., Sauters, E. A. Howes, A. D., Araji, A. A., Gregory, T. L. and Hust, C. E. 1977. Bulls versus steers. II. Palatability and retail acceptance. J. Anim. Sci. 45:699-702.

20. Jeremiah, L. E. 1978. A review of factors affecting meat quality. Tech. Bull. 1, Research Branch, Agriculture Canada.

21. Landon, M. E., Hedrick, H. B. and Thompson, G. B. 1978. Live animal performance and carcass characteristics of beef bullocks and steer. J. Anim. Sci. 47:151-155.

22. Lizaso, G., Hernadez, B., Chasco, J., Insausti, K., Beriain, M. J. and Purroy, A. 1996. Meat colour from pirencia steers and heifers after vacuum packaging. Proceedings of the 42nd ICoMST., 1:98-99.

23. Mercier, Y., Gatellier, P., Viau, M., Remignon, H. and Renerre, M. 1998. Effect of Dietary fat and vitamin $\mathrm{E}$ on colour stability and on lipid and protein oxidation in turkey meat during storage. Meat Sci., 48 301-318.

24. Ministry of Agriculture and forest (MAF). 2007. Information and data of agricultural statistics of Korea. http://www.english.maf.go.kr/index.jsp (assessed on July 30, 2007).
25. Reagan, J. O., Carpenter, Z. L., Smith, G. C. and King, G. T. 1971. Comparison of palatability traits of beef produced by young bulls and steers. J. Anim. Sci. 32:641-646.

26. Sakata, R. and Nagata, Y. 1992. Heme pigment content in meat as affected by the addition curing agents. Meat Sci. 32:343-350.

27. Santamaria, I., Lizarraga, T., Astiasaran, I. and Bello, J. 1992. Contribucion alproblema del desarrollo del color en al Chorizo de Pamplona : comportamiento de nitritos, nitratosy pigmentos carnicos. Alimentaria, 1:23-26.

28. Sanz, M. C., Verde, M. T., Saez, T. and Sanudo, C. 1996. Effect of breed on the muscle glycogen content on dark cutting incidence in stressed young bulls, Meat Sci. 43:37-42.

29. SAS. 1996. SAS STAT User's Guide, Statistics, Cary NC.

30. Seideman, S. C., Cross, H. R., Oltjen, R. R. and Schanbacher, B. D. 1982. Utilization of the intact male for red meat production : Review. J. Anim. Sci. 55(4):826-840.

31. Smith, D. R., Nuir, P. D. and Smith, N. B. 1997. Between and within Mob Variation in meat and fat colour of pasture finished steers. Proceedings of the 43rd ICoMST., 1:338-339.

32. Yang, A., Larsen, T. W., Powell, V. H. and Tume, R. K. 1999. A comparison of fat composition of Japanese and long-term grain-fed Australian steers. Meat Sci. 51:1-9.

33. Watson, M. J. 1969. the effects of castration on the growth and meat quality of grazing cattle. Australian J. Exp. Agr. Husb. 9:164-167.

34. Weninger, J. H. and Steinhauf, D. 1968. Meat quality in respect to carcass evaluation in cattle. World Rev. of Anim. Prod. 4:87.

35. Watanabe, A., Daly, C. C. and Devine, C. E. 1996. The effects of the ultimate $\mathrm{pH}$ of meat on tenderness charges during ageing. Meat. Sci. Vol. 42:67-78.

36. Wheeler, T. L., Shackelford, S. D. and Koohmaraie, M. 2000. Relationship of beef long- 
issimus tenderness classes to tenderness of gluteus medius, semimembrano and biceps femoris. $\mathrm{J}$. Anim. Sci., 78, 2856-2861.

37. 강종옥, 최도영, 오홍록, 김기환. 1999. 등급별 국 내산 한우육과 국별 수입우육의 물리화학적 특 성비교-육색, 지방색, 성숙도에 관한 고찰. 한국 동물자원학회지. 41(5):555-562.

38. 김대곤, 정근기, 성삼경, 최창본, 김성겸, 김덕영, 최봉재. 1996. 거세가 한우 및 홀스타인 비육우 도체의 이화학적 특성에 미치는 영향. 한국축산 학회지. 38:239-248.

39. 김병철, 오세종. 1990 . 한우육과 홀스타인육의 이 화학적 성질에 관한 비교연구. 고려대학교 농림 논집. 107.

40. 김선구, 이길왕, 이종문, 정숙근. 1982. 육 및 육 제품제조와 품질에 관한 연구. 축시보고서. 668.

41. 농림기술개발사업최종보고서, 2001. 육류의 저장 및 유통개선을 위한 기술개발, 농림부.

42. 소 및 돼지고기 부분육 분할 정형 지침서, 1997.
축산과학원

43. 백봉현, 이병석, 강희설, 김용곤, 박명국, 이근상. 1992. 한우의 거세시기가 육질 및 육생산에 미치 는 영향. 농시연보. p.62.

44. 이길왕, 김용곤, 정숙근, 차장옥, 백영기, 송계원. 1981. 쇠고기의 분할방법 및 해부학적 특성과 이 용법 규명에 관한연구. 축시연보. 580.

45. 채영석, 강창기, 김동학. 1983. 한우 사육형태가 육질에 미치는 영향. 2. 이화학적 특성. 한국축산 학회지. 25:629.

46. 三律本 充, 山下 良弘, 三橋忠由, 中西直人. 1987. 黑手和穜去勢牛における胸長筋の理化學 的 特性と格付等級との關係. 中國試報. B, 29: 35.

47. 吉田正三郎, 上田敬介, 寺田降慶, 田中彰治, 小 尺忍， 1968. 若䇅令肥育における雄牛と去勢牛の 産肉性の比較, 中國農試報, 16: 873.

(접수일자 : 2007. 9. 13. / 채택일자 : 2007. 12. 19.) 